\begin{tabular}{|c|c|c|}
\hline & $\begin{array}{c}\text { International Journal of Current Research in } \\
\text { Biosciences and Plant Biology } \\
\text { EXCELLENT } \\
\text { PUBLISHERS }\end{array}$ \\
Volume $4 \bullet$ Number 7 (July-2017) $・$ ISSN: 2349-8080 (Online) \\
Journal homepage: www.ijcrbp.com
\end{tabular}

\title{
Jasminum pentaneurum Hand.-Mazz. (Oleaceae): An Addition to Indian Flora from Arunachal Pradesh, North East India
}

\author{
K. Jeyaprakash ${ }^{1}$, K. Karthigeyan ${ }^{2}$ and S. Rathinavel ${ }^{3}$ \\ ${ }^{I}$ North Eastern Institute of Folk Medicine (Ministry of AYUSH, Govt. of India), Pasighat-791 102, East Siang District, \\ Arunachal Pradesh, India \\ ${ }^{2}$ Botanical Survey of India, Central National Herbarium, Howrah -711 103, West Bengal, India \\ ${ }^{3}$ Department of Botany, Saraswathi Narayanan College (Autonomous), Perungudi, Madurai-625 022, Tamil Nadu, India
}

*Corresponding author.

\begin{abstract}
Jasminum pentaneurum Hand.-Mazz. (Oleaceae) is reported for the first time in India from Arunachal Pradesh. This species differs from other Indian Jasminum spp. by bearing conspicuous leafy bracts at the base of the inflorescence. Detailed description along with notes on its habitat and ecology and photographs are provided for easy identification. Additionally, a comparison of the diagnostic characters between this species and other Indian species are made and also provided its conservations status.
\end{abstract}

\section{Article Info}

Accepted: 02 July 2017

Available Online: 06 July 2017

\section{Keywords}

Arunachal Pradesh Jasminum pentaneurum

New record to India

\section{Introduction}

Jasmines are the one among the most interesting group of flowering plants widely cultivated for their attractive and fragrant flowers. They are grown in gardens as decorative shrubs in landscaping, for making garlands, hair decoration and for extraction of essential oil which is a highly lucrative business of late for scent-making and perfuming tea (Mabberley, 2008).

The genus Jasminum L. is an old world genus comprising about 200 species, especially in the tropics but with a few in warm temperate regions. The genus is distributed from the Mediterranean region, Africa, Europe, Asia, Australia and the South Pacific Islands (Kobuski, 1932; Green, 1995, 2000 and 2003; Chang et al., 1996). Clarke (1882) enumerated a total of 53 taxa belonging to 43 species for the flora of British India.

A total of 53 taxa were reported from the Indian Subcontinent (Green, 2003), of which 17 species are reported as rare and threatened (Srivastava and Kapoor, 1987). A total of 12 taxa are endemic to India (Srivastava, 1987; Singh et al., 2015).

In Arunachal Pradesh, so far 16 species are known to occur viz. J. adenophyllum, J. attenuatum, J. caudatum, $J$. coarctatum, J. dispermum subsp. forrestianum, $J$. elongatum, J. flexile, J. grandiflorum, J. humile, J. lanceolaria, J. laurifolium var. laurifolium, J. listeri, $J$. multiflorum, J. nepalense, J. nervosum and J. sambac (Green, 2003; Chowdhery et al., 2008). 


\section{Materials and methods}

During a recent plant exploration tour to Yaapgo area in Pasighat a species of Jasminum was collected. On critical study of relevant literature (Clarke, 1882; Green, 2003; Chauhan et al., 1996; Chowdhery et al., 2008; Deb, 1983; Haridasan and Rao, 1987; Kanjilal et al., 1939; Chang et al., 1996; Bora and Kumar, 2003; Ambrish, 2013) and consultation of herbarium depositions at ARUN, ASSAM, BSHC and CAL the specimen was identified as Jasminum pentaneurum Hand.-Mazz., a species so far not reported from Arunachal Pradesh as well as for the flora of India. Therefore the present collection forms a new distributional record for the flora of India. Brief description and notes on its geographical distribution, habitat and ecology along with photographs are provided for easy identification.

A dichotomous key to the Jasminum spp. occurring in Arunachal Pradesh is also provided. The voucher specimens are deposited at CAL and at North Eastern Institute of Folk Medicine, Pasighat, Arunachal Pradesh, for future reference.

\section{Results and discussion}

\section{Taxonomic treatment}

Jasminum pentaneurum Hand.-Mazz. in Anz. Akad. Wiss. Wien, Math.-Naturwiss. K1. 59: 110. 1922; Kobuski in J. Arnold Arbor. 13: 167. 1932; Chang et al., Fl. China 15: 316. 1996.

Scandent shrubs, 2-3 m; branchlets terete, glabrous. Leaves simple, opposite; petiole ca. $8 \mathrm{~mm}$, articulate at base, canaliculate, twisted; leaves ovate-lanceolate, 3-7 × 2-6.5 $\mathrm{cm}$, rounded to cuneate or sub truncate at base, entire to faintly undulate at margins, long acuminate at apex, prominently 3-veined at base, apex acuminate leathery, glabrous, dark green above, pale beneath. Inflorescence in 2-3 flowered cymes, terminal or axillary; bracts green, leafy, $1-3 \times 0.5 \mathrm{~cm}$. Flowers white, fragrant; pedicel 1$\mathrm{mm}$, pubescent. Calyx lobes $c a$. 6-8, pale green, linear, 1-2 $\mathrm{cm}$ long, glabrous. Corolla white, tube $2-2.2 \mathrm{~cm}$; lobes $6-8$, lanceolate, $10-25 \times 3.5 \mathrm{~mm}$, glabrous. Stamens 2, included, inserted at middle of corolla tube; filaments short; anthers yellow, ca. $5 \times 1 \mathrm{~mm}$, dorsifixed, introrse. Style 5-7 mm, filiform; stigma 2-lobed. Berries green turning black on ripening, reniform, 1-1.5 $\mathrm{cm} \times 6-8 \mathrm{~mm}$, glabrous (Fig. 1).

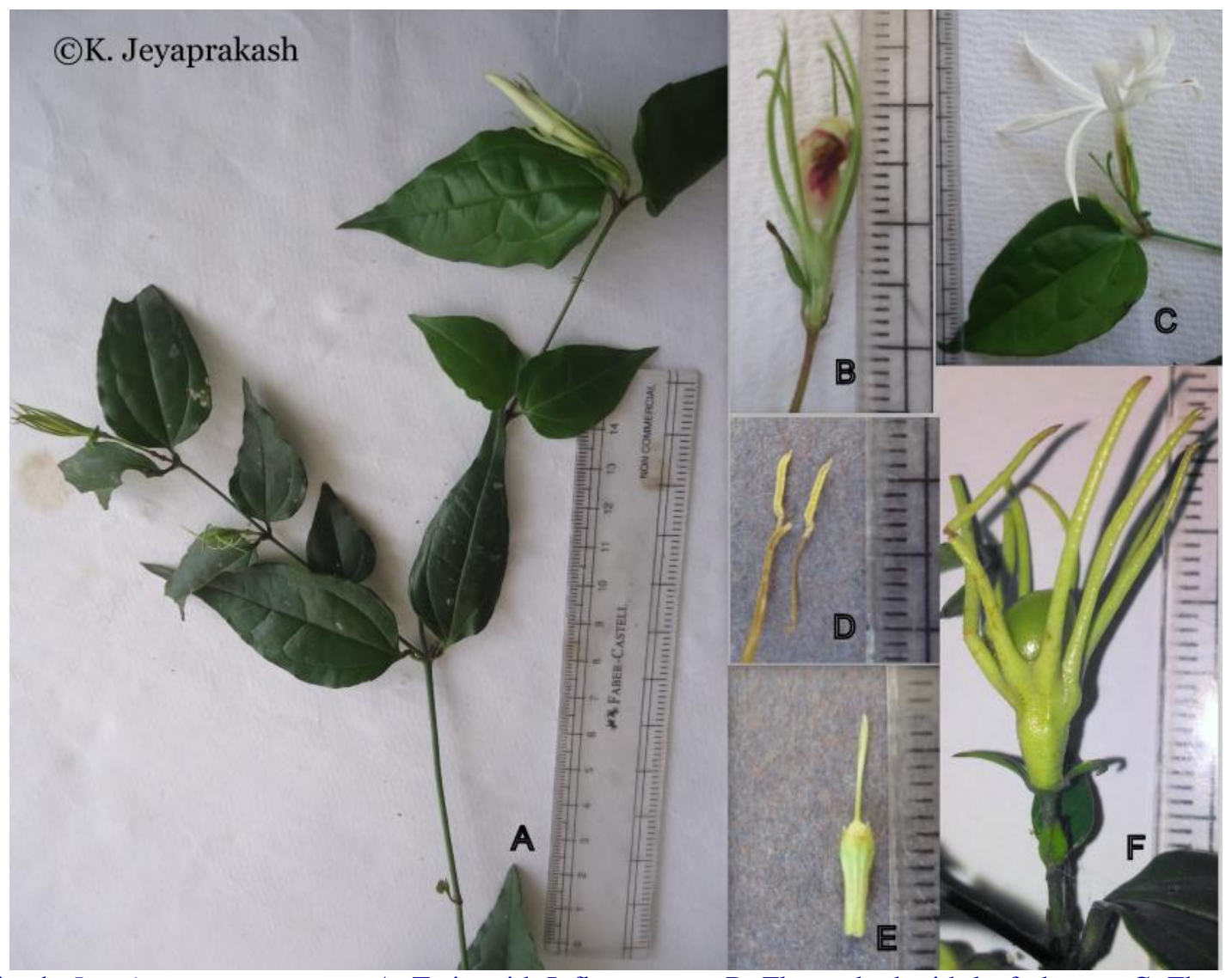

Fig. 1: Jasminum pentaneurum: A. Twig with Inflorescence; B. Flower bud with leafy bracts; C. Flower with leafy bracts; D. Stamens; E. Gynoecium with style; F. Fruit. 
Flowering and Fruiting: February-June

Distribution: India (Arunachal Pradesh); China (Guangdong, Guangxi, Hainan) and Vietnam.

Habitat and ecology: This species is occasionally found in evergreen forests along the stream sides on rocky slopes, at $183-220 \mathrm{~m}$ elevations. Its local distribution is fragmented and the population is represented by many scattered individuals. Only 07 individuals were located in the evergreen forest slopes and edges of streamlets at Yaapgo village (north-west of Pasighat town) and 10 individuals (3 matured and 7 seedlings) were located from forest plantation area near Sibo Korong River Bridge (north of Pasighat town). The commonly associated species in the habitat include Brucea mollis
Wall. ex Kurz, Cyathula prostrata (L.) Blume, Crateva magna (Lour.) DC., Dioscorea bulbifera L., Elatostema sessile J.R.Forst. \& G.Forst., Eleutherococcus trifoliatus (L.) S.Y. Hu, Elsholtzia blanda (Benth.) Benth., Erythropalum scandens Blume, Leptopus clarkei (Hook.f.) Pojark., Oxyspora paniculata var. paniculata (D.Don.) DC., Persicaria chinensis (L.) H. Gross., Piper sylvaticum Roxb., Rauvolfia verticillata (Lour.) Baill., Solanum spirale Roxb., and Tabernaemontana divaricata (L.) R.Br. ex Roem. \& Schult.

Specimen examined: INDIA: Arunachal Pradesh: East Siang Dist.: Pasighat: Yaapgo village; $220 \mathrm{~m}$ MSL; $28^{\circ}$ 03' 36.0936" N longitude \& $95^{\circ} 17^{\prime} 48.8508^{\prime \prime}$ E latitude; K. Jeyaprakash NEIFM-00445; dated 28-2-2016 (Fig. 2).

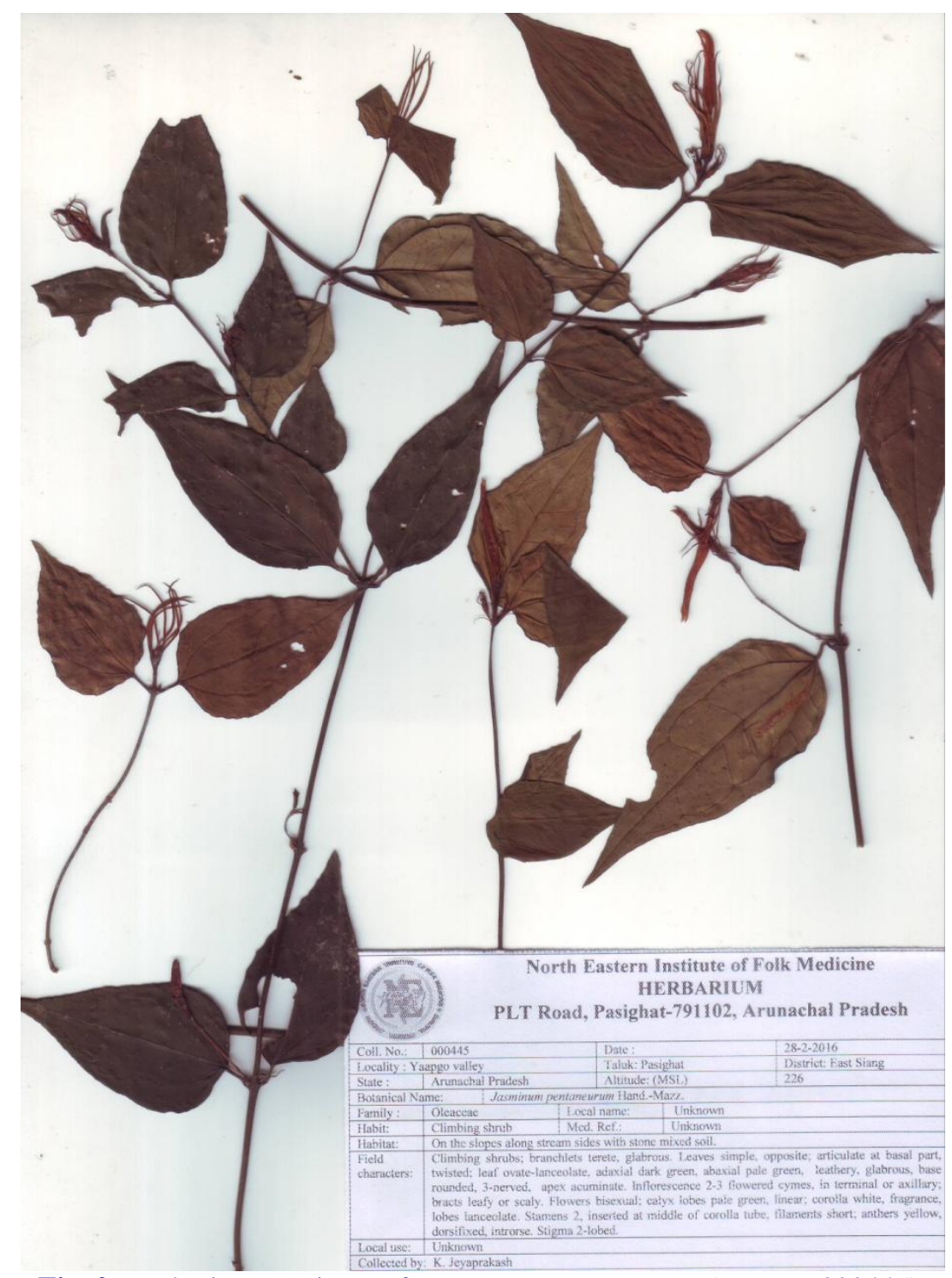

Fig. 2: Herbarium specimen of Jasminum pentaneurum (NEIFM-000445). 
Key to the species of Jasminum in Arunachal Pradesh

1a. Leaves all simple, unifoliolate (Section Unifoliolata)..........................2

1b. Leaves all, or at least a few compound, pinnate or trifoliolate .................12

2a. Leaves with primary veins pinnately arranged, without prominent basal veins...3

2b. Leaves prominently 3 or 5 -veined at base ................................ 10

3a. Inflorescences open, lax, 1 -5-flowered................................. 4

3b. Inflorescences dense, many flowered..................................... 8

4a. Corolla lobes almost equalling the tube ...................................5

4b. Corolla lobes much shorter than the tube...................................6

5a. Leaves lanceolate, acuminate; cymes axillary ........................... listeri

5b. Leaves ovate to broadly elliptic, acute; cymes terminal.................... sambac

6a. Calyx lobes long, filiform, 5-14 mm long; berries spheroidal................ adenophyllum

6b. Calyx lobes short, teeth like, $0.25-1 \mathrm{~mm}$; berries ellipsoid.....................7

7a. Petioles 10 - $20 \mathrm{~mm}$ long; cymes 3- many flowered...................... attenuatum

7b. Petioles up to $5 \mathrm{~mm}$ long; cymes 1 or rarely 3 -flowered.................. nepalense

8a. Leaves with $4-7$ pairs of lateral veins; bracts white or cream; inflorescence terminal, on a distinct

peduncle............................................................ coarctatum

8b. Leaves with $2-4$ pairs of lateral veins; bracts green, leafy; inflorescence axillary or terminal on

axillary side-shoots........................................................... 9

9a. Leaves velutinous to densely pilose beneath; corolla tube $12-17 \mathrm{~mm}$ long...J. multiflorum

9b. Leaves appressed pilose to glabrous beneath; corolla tube $15-25 \mathrm{~mm}$ long...J. elongatum

10a. Basal bracts leaf-like, $1-3 \mathrm{~cm}$ long; pedicels pubescent.................. pentaneurum

10b. Basal bracts not leaf-like, $1-1.3 \mathrm{~cm}$ long; pedicels glabrous..................11

11a. Leaves over 5 times as long as broad; inflorescence 3-5

flowered.

.J. laurifolium var. laurifolium

11b. Leaves less than 3 times as long as broad; inflorescence 1 - rarely 3 -

flowered.

.J. nervosum

12a. Leaves alternate (Section Alternifolia)................................ humile

12b. Leaves opposite.......................................................

13a. Leaves pinnate (Section Jasminum) ................................. grandiflorum

13b. Leaves trifoliolate (Section Trifoliolata).................................... 14

14a. Leaves coriaceous; petioles stout..................................... lanceolaria

14b. Leaves chartaceous; petioles slender........................................ 15

15a. Inflorescence sub umbellate; corolla tube up to $12 \mathrm{~mm}$ long.....

J. dispermum subsp. forrestianum

15b. Inflorescence cymose - paniculate; corolla tube 20-30 mm long...................16

16a. Petiole 1-2 cm long; leaflets acute to shortly acuminate, domatia absent......... flexile

16b. Petiole 3-4 cm long; leaflets caudate acuminate at apex; domatia distinct, 3-6, tufted.

J. caudatum

Flowering and fruiting: February-June

Distribution: India (Arunachal Pradesh); China (Guangdong, Guangxi, Hainan) and Vietnam.

Conservation status: Jasminum pentaneurum has been found in growing with stone mixed soil in disturbed as well as undisturbed areas in the forest area of Yaapgo village, on the slopes along stream sides of Sibo Korong river area and NEIFM campus of Pasighat, Arunachal Pradesh where individuals of many populations grow well. Thus, the species is probably not at risk.

\section{Conclusion}

The present investigation assumed to provide the baseline information on the genus that can be useful for further research on conservations and field surveys to improve data about the Indian Jasminum species. 


\section{Conflict of interest statement}

Authors declare that they have no conflict of interest.

\section{Acknowledgement}

The first author is thankful to The Director and other officials of North Eastern Institute of Folk Medicine (Ministry of AYUSH, Govt. of India), Pasighat, East Siang District, Arunachal Pradesh for his encouragement and providing facilities for carryout research work and Dr. N. Balachandran, Botanist, French Institute of Pondicherry also acknowledged for his help in identification.

\section{References}

Ambrish, K., 2013. Floristic Diversity of Arunachal Pradesh: Upper Subansiri District. Bishen Singh Mahendra Pal Singh, Dehra Dun. 312p.

Bora, P.J, Kumar, Y., 2003. Floristic Diversity of Assam: Study of Pabitora Wildlife Sanctuary. Daya Publishing House, Delhi. 211p.

Chang, M-C., Chiu L.-C., Wei, Z., Green, P.S., 1996. In: Flora of China (Eds.: Wu, Z.Y., Raven, P.H., Hong, D.Y.). Science Press, Beijing, Missouri Botanical Garden Press, St. Louis.

Chauhan, A.S., Singh, K.P., Singh, D.K., 1996. A Contribution to the Flora of Namdapha, Arunachal Pradesh (Ed.: Hajra, P.K.). Botanical Survey of India, Calcutta. pp.214-216.

Chowdhery, H.J., Giri, G.S., Pal, G.D., Pramanik, A., Das, S.K., 2008. Materials for the Flora of Arunachal Pradesh. Vol.1. (Ranunculaceae Dipsacaceae). Botanical Survey of India, Calcutta. pp.142-148.

Clarke, C.B., 1882. Oleaceae. In: Flora of British India (Hooker, J.D.). Vol. 3. (Caprifoliaceae to
Apocynaceae). L.Reeve \& Co., London. pp.591603.

Deb, D.B., 1983. The Flora of Tripura State. Vol. 2. (Buddlejaceae-Gramineae). Today \& Tomorrow's Printers and Publishers, New Delhi. pp.3-9.

Green, P. S., 2000. Oleaceae. In: Flora of Thailand (Eds.: Santisuk, T., Larsen, K.). Vol. 7. The Forest Herbarium, Royal Forest Department, Bangkok. Thailand. pp.271-340.

Green, P. S., 2003. Synopsis of the Oleaceae from the Indian Sub-Continent. Royal Botanic Gardens, Kew. Kew Bull. 58(2), 257-295.

Green, P.S., 1995. New species and combinations in Jasminum, especially from Thailand studies in the genus Jasminum (Oleaceae): XIV. Royal Botanic Gardens, Kew. Kew Bull. 50(3), 567-580.

Haridasan, K., Rao, R.R., 1987. Forest Flora of Meghalaya. Vol. 2: Caprifoliaceae to Salicaceae. Bishen Singh Mahendra Pal Singh, Dehra Dun. pp.584-588.

Kanjilal, U.N., Das, A., Kanjilal, P.C., De, R.N., 1939. Flora of Assam. Vol. 3: Caprifoliaceae to Plantaginaceae. Government of Assam, Shillong. pp.222-244.

Kobuski, C.E., 1932. Synopsis of the Chinese species of Jasminum. J. Arnold Arbor. 13, 145-179.

Mabberley, D.J., 2008. Mabberley's Plant - Book. A Portable Dictionary of Plants, their Classification and Uses. Cambridge University Press, United Kingdom. 1021p.

Singh, P., Karthigeyan, K., Lakshinarasimhan, P., Dash, S.S., 2015. Endemic Vascular Plants of India. Botanical Survey of India, Kolkata. 215p.

Srivastava, S. K., 1987. Oleaceae in Himalaya. J. Econ. Taxon. Bot. 9(1), 187-192.

Srivastava, S.K., Kapoor, S.L., 1987. Notes on conservation status of taxa of Indian Oleaceae. J. Econ. Taxon. Bot. 9(1), 173-177.

\section{How to cite this article:}

Jeyaprakash, K., Karthigeyan, K., Rathinavel, S., 2017. Jasminum pentaneurum Hand.-Mazz. (Oleaceae): An addition to Indian flora from Arunachal Pradesh, North East India. Int. J. Curr. Res. Biosci. Plant Biol. 4(7), 129-133. doi: https://doi.org/10.20546/ijcrbp.2017.407.016 